\title{
Dissemination in Pigtailed Macaques after Primary Infection of Dengue-3 Virus
}

\author{
JOKO PAMUNGKAS ${ }^{1,2 *}$, DIAH ISKANDRIATI ${ }^{1,3}$, UUS SAEPULOH $^{1}$, MOSES AFFANDI $^{4}$, \\ ESTHER ARIFIN $^{1,3}$,YASMINA PARAMASTRI ${ }^{1,3}$, FITRIYA NUR ANISA DEWI $^{3}$, AND DONDIN SAJUTHI ${ }^{1,2}$ \\ ${ }^{I}$ Primate Research Center, Institut Pertanian Bogor, Jalan Lodaya II/5, Bogor 16151, Indonesia; \\ ${ }^{2}$ Faculty of Veterinary Medicine, Institut Pertanian Bogor, Jalan Agatis Darmaga, Bogor, Indonesia; \\ ${ }^{3}$ PT. Bimana Indomedical, Jalan KH Rd Abdullah bin Nuh 3, Sindangbarang, Bogor 16115, Indonesia; \\ ${ }^{4}$ Faculty of Biotechnology, Unika Atma Jaya, Jalan Jenderal Sudirman 51, Jakarta 12930, Indonesia
}

\begin{abstract}
Nonhuman primates (NHPs) play as indispensable animal model in biomedical research for studying a variety of human health issues, diseases and disorders, therapies, and preventive strategies. Since the immunological and physiological responses of NHPs, at some extent, to experimental viral infections are similar to humans, it is possible that studies of dengue infection in NHPs may aid understanding of dengue infection in humans. In this study, we used pigtailed macaques (Macaca nemestrina) as the experimental animal to study dengue-3 (DEN-3) virus infection. We evaluated DEN-3 viral distribution and replication sites after a primary infection in all collected tissues. Sequential localization in tissue of DEN-3 virus was studied in pigtailed macaques euthanized three days post viral inoculation $\left(10^{7} \mathrm{pfu} \mathrm{mL}^{-1}\right)$. Pigtailed macaque that was inoculated subcutaneously or intravenously; showed the highest viremia $\left(62.94 \mathrm{pfu} \mathrm{mL} \mathrm{m}^{-1}\right.$ and $\left.58.62 \mathrm{pfu} \mathrm{mL}^{-1}\right)$ detected by one step reverse transcription real time PCR. The virus inoculated in pigtailed macaques by subcutaneous injection was rapidly disseminated from the inoculation site to the lymph nodes, adrenal glands, kidneys, heart, thyroid, liver, prostate gland, and seminal vesicles. Meanwhile, dissemination of dengue virus in pigtailed macaques inoculated intravenously was detected in lymph nodes, thymus, salivary glands, liver, and prostate gland. This study suggested that the above mentioned-tissue specimens are involved or affected by DEN-3 virus replication and the route of infection seemed to have influenced the virus dissemination.
\end{abstract}

Key words: Macaca nemestrina, animal model, dengue-3 virus, dissemination, RT-PCR

Satwa primata merupakan hewan model yang sangat penting dalam penelitian biomedis untuk memperlajari berbagai permasalahan kesehatan manusia, terutama terkait pengobatan dan strategi pencegahannnya. Mengingat keadaan respons fisiologi dan respons kebal satwa primata terhadap infeksi virus mirip dengan yang dijumpai pada manusia, sangat dimungkinkan bahwa penelitian infeksi virus dengue pada satwa primata bisa membantu pemahaman tentang infeksi virus dengue pada manusia. Pada penelitian ini, digunakan beruk (Macaca nemestrina) sebagai hewan percobaan untuk mempelajari infeksi virus dengue serotipe-3 (DEN-3). Setelah diinfeksi dengan virus DEN-3, distribusi dan tempat replikasi virus DEN-3 dievaluasi pada semua jaringan tubuh yang diambil; Tahap lanjutan lokalisasi dari replikasi virus DEN-3 pada jaringan dipelajari pada beruk yang di-etanasi tiga hari setelah diinfeksi virus DEN-3 $\left(10^{7} \mathrm{pfu}\right.$ $\left.\mathrm{mL}^{-1}\right)$. Beruk yang diinokulasi melalui rute subkutan atau rute intravena menunjukkan titer viremia tertinggi $\left(62.94 \mathrm{pfu} \mathrm{mL}^{-1}\right.$ dan $58.62 \mathrm{pfu} \mathrm{mL}^{-1}$ ) yang dideteksi dengan metode one step reverse transcription real time PCR. Virus yang diinokulasikan ke beruk melalui rute subkutan secara cepat mengalami diseminasi ke kelenjar limfa, kelenjar adrenal, ginjal, jantung, tiroid, hati, kelenjar prostat, dan kandung kemih. Sementara diseminasi virus pada beruk yang diinokulasi melalui rute intravena dapat dideteksi pada kelenjar limfa, timus, kelenjar air liur, hati, dan kelenjar prostat. Hasil penelitian ini menunjukkan bahwa replikasi virus DEN-3 terjadi pada berbagai jaringan tersebut dan perbedaan rute infeksi diindikasikan berpengaruh terhadap diseminasi virus.

Kata kunci: Macaca nemestrina, hewan model, virus dengue-3, diseminasi, RT-PCR

Dengue (DEN) viruses are mosquito-borne RNA viruses, which belong to the family Flaviviridae, and are grouped into four antigenically distinct types, DEN-1, DEN-2, DEN-3, and DEN-4. Dengue virus infection in recent decades has become a major international public health concern and it has been reported to cause several clinical consequences in humans; Dengue fever (DF) is an acute, self limited febrile illness, but infection might also result in a more severe form, dengue hemorrhagic fever (DHF) with thrombocytopenia and capillary leakage and might

*Corresponding author, Phone: +62-251-8313637, Fax.+62-251-8360712, E-mail: jpi-pssp@indo.net.id process to a life threatening hypovolemic shock, dengue shock syndrome (DSS) (Peng et al. 2004; Bente and Rico-Hesse 2006). According to WHO (2009), the incidence of dengue infection has grown dramatically around the world; about 2.5 billion people which are two fifths of the world's population are now at risk from dengue infection. WHO estimates there may be 50 million dengue infections worldwide every year.

Understanding the dengue virus pathogenesis has been extremely difficult because only human seem to develop this disease clinically. Target cells and organs for DEN replication in humans remain unclear. The involvement of liver cells in the pathogenesis of DEN 
virus infection has been indicated by abnormal liver function, pathological findings, and detection of viral antigen in hepatocytes at biopsy from human tissue and mice model (Peng et al. 2004; Basilio-de-Oliveira et al. 2005, Paes et al. 2009). Strong tissue alteration associated with DHF/ DSS are observed in the liver, bone marrow, lymphoid organ, heart, lung, and kidney of tissues collected at autopsy (Basilio-de-Oliveira et al. 2005)

To better understand the pathogenesis of DEN virus infection, animal model is necessary to reveal the detailed symptoms and distribution of the virus in tissues, as well as the histopathological findings associated with DEN virus infection. The genetic similarity of NHPs to human had been reported to have consequences in their role as hosts to the same pathogens; this could mean that there is (are) critical molecule(s) shared by NHPs and human being used by pathogens in their life cycle. Thus the NHPs often are the only species that can be infected by human pathogen (Bennet et al. 1998). The detection of dengue antibodies in sera from NHPs in sylvatic or rural setting of Asia and Africa suggest that they are involved in DEN virus transmission (De Silva et al. 1999). Several studies using NHP models have been done in the past six decades. Although there were no clinical signs detected in DEN infected-NHPs, researchers could show that these animals were susceptible to DEN infection with viremia level reported to be lower than $100 \mathrm{pfu} \mathrm{mL}^{-1}$ (Bente and Rico-Hesse 2006). It is very unfortunate that until recently there is limited information regarding the target cells and organs for virus replication in this model. Recent study by Onlamoon et al. (2010) described the hemorrhage induction in rhesus macaques (Macaca mulatta) by DEN-2 virus infection.

It is the intention of this study to show the susceptibility of pigtailed macaques (Macaca nemestrina) to DEN infection and to show that the infection caused the dissemination of DEN virus in organs of pigtailed macaques infected with DEN-3, as well as analyzing the pathological finding in various organ.

\section{MATERIALS AND METHODS}

Viruses. DEN-3 virus 98900645 was isolated from human case of DSS in Indonesia by passaging five times in C6/36 cells (kindly provided by Dr Maya Williams of the Viral Disease Program, US NAMRU2, Jakarta, Indonesia)

Animals and Housing. Study was carried out using protocol reviewed and approved by the Institutional
Animal Care and Use Committee (PT. Bimana Indomedical number P.09-08-IR). Fourteen pigtailed macaques at 4 to 6 year of age were obtained from the colony maintained by the Primate Research Center at Bogor Agricultural University, in Bogor, Indonesia. During the study, pigtailed macaques were housed in individual stainless steel cages in climate-controlled room $\left(24 \pm 2{ }^{\circ} \mathrm{C}\right.$ and $30-70 \%$ humidity $)$. They were fed with commercial monkey chow and supplemented with fruits. Water was available ad libitum. Environmental enrichment was given to the pigtailed macaques to assure that their welfare issue was not neglected.

Pigtailed macaques used in this study were negative to DEN-1, $-2,-3$ and -4 viral antibodies as previously screened by ELISA (Human Gesellschaft fur Biochemia und Diagnostica mbH, Germany). Prior to virus inoculation and each blood collection, pigtailed macaques were anesthetized with intramuscular injection of Ketamil ${ }^{\circledR}$ (Ketamine Hydrochloride 10\%; Troy Laboratories Pty. Ltd., NSW, Australia). Daily observation was conducted intensively to assess pigtailed macaque's clinical condition.

Infection of Pigtailed Macaques. Pigtailed macaques were randomly divided into three treatment groups (4 animals per-group) and a control group (2 animals). Anesthetized pigtailed macaques were inoculated subcutaneously (SC) on the upper back, intradermally (ID) on the left and right abdomen and intravenously (IV) on saphenous veins of the left and right legs with $1 \mathrm{~mL}$ of DEN-3 virus at $10^{7}-10^{8} \mathrm{pfu} \mathrm{mL}^{-1}$. Control pigtailed macaques received $1 \mathrm{~mL}$ of media (DMEM) subcutaneously.

Viremia Level Detection. Blood samples were collected from femoral vein of all pigtailed macaques on day $0,1,2$, and 3 post inoculation (p.i). Plasma samples were obtained and titrated for DEN-3 virus by real-time RT-PCR (iQ5 Multicolor Real Time PCR, BioRad) using primer and probe (Taqman). The values in PFU per milliliter for each RNA standard was based on the original titer of stock virus as determined by plaque assay. Both the real time PCR protocol and PFU per milliliter conversion were done as previously described by Callahan (2001).

Pathology and Histopathology. Six treated pigtailed macaques ( 2 animals per group) were humanely euthanized with intravenous injection of Euthal ${ }^{\circledR}$ (sodium pentobarbital and phenytoin; a Croesus Pharma Inc, Philippines) on day two p.i for macroscopic evaluation. Liver, spleen, adrenal gland, kidney, stomach intestines, reproductive organs (ovary, testicle, uterus, prostate gland, seminal vesicle), urinary bladder, lymph nodes (axillary, 
mesenteric, inguinal, submandibular), thyroid gland, heart, lung, aorta, trachea, esophagus, brain, pituitary gland, eye, oral mucosa, abdominal skin, skin of inoculation site, and mammary gland (if applicable) were fixed in $10 \% \mathrm{NBF}$ and stained with routine hematoxylin-eosin (HE) for light microscopic evaluation.

Tissue Processing. Tissue samples for RNA isolation were all collected organs from necropsy. $200 \mu \mathrm{L}$ extraction buffer (phosphate buffer saline, EDTA, SDS, and protease) was added into each minced tissue to destruct the cells and protein. Tissues were placed in vials and incubated overnight at $56{ }^{\circ} \mathrm{C}$. QIAamp RNA Viral Mini Kit (Qiagen) was used to extract the viral RNA from samples.

Reverse Transcriptase Polymerase Chain Reaction. Primers set used in the PCR were adapted from Callahan et al. (2001). The primers produced 124 base pair (bp) of amplicon. $50 \mathrm{uL}$ of One Step Reverse Transcriptase (Qiagen) was added to 10 pmol each of the primers and DNA template. Positive, negative controls, and one or more reagent controls were included in each run. PCR amplification was carried out in GeneAmp 9700 Thermal Cycler under the following conditions: $50{ }^{\circ} \mathrm{C}$ for $15 \mathrm{~min}$ and $94{ }^{\circ} \mathrm{C}$ for 30 min to produced cDNA from samples, followed by amplification of 45 cycles at $94{ }^{\circ} \mathrm{C}$ for $30 \mathrm{sec}$ for denaturation, at $60^{\circ} \mathrm{C}$ for $30 \mathrm{sec}$ for primers annealing, at $72{ }^{\circ} \mathrm{C}$ for $30 \mathrm{sec}$ for elongation then ended with extension for $10 \mathrm{~min}$ at $72{ }^{\circ} \mathrm{C}$ and finally stored at $4{ }^{\circ} \mathrm{C}$. PCR product was analyzed by $2 \%$ of agarose gel electrophoresis and visualized using Gel Doc (Biorad GelDoc 2000).

\section{RESULTS}

The DEN-3 98900645 induced viremia in all 14 infected pigtailed macaques with duration from 1 to 4 days with peak titer on day 2 p.i (Table 1). All pigtailed macaques remained healthy and did not show any signs of disease although viremia was detectable. Viremia levels on day 2 p.i. were at $62.94 \mathrm{pfu} \mathrm{mL}^{-1}$ (1.5799, SC), $10.68 \mathrm{pfu} \mathrm{mL}^{-1}$ (F9004, SC), $47.98 \mathrm{pfu}$ $\mathrm{mL}^{-1}$ (1.6087, ID), $15.64 \mathrm{pfu} \mathrm{mL}^{-1}$ (1.6136, ID), 58.62 pfu $\mathrm{mL}^{-1}$ (M9008, IV), and $4.09 \mathrm{pfu} \mathrm{mL}^{-1}$ (1.5808, IV); these were the highest and the lowest viremia levels in each treatment group.

These pigtailed macaques were submitted for necropsy immediately after euthanasia. All pigtailed macaques were in healthy condition with adequate body fat stores; significant gross lesions were not seen in any of the examined pigtailed macaques. Mild to moderate erythema and skin crusting at the inoculation
Table 1 DEN-3 virus viremia level in Macaca nemestrina detected by reverse transcripatse real time $\mathrm{PCR}\left(\mathrm{pfu} \mathrm{mL}^{-1}\right.$ )

\begin{tabular}{lrrrrr}
\hline Monkey ID & Day 0 & Day 1 & Day 2 & Day 3 & Day 4 \\
\hline 1.1 .3251 & $<1.00$ & 1.93 & 12.19 & 1.47 & $<1.00$ \\
1.5799 & $<1.00$ & 9.37 & 62.94 & $<1.00$ & $<1.00$ \\
F9004 & $<1.00$ & 8.73 & 10.68 & 6.53 & $<1.00$ \\
9350 & $<1.00$ & 7.50 & 14.56 & 3.90 & $<1.00$ \\
1.6087 & $<1.00$ & 11.57 & 47.98 & $<1.00$ & $<1.00$ \\
1.8258 & $<1.00$ & 1.62 & 24.34 & 35.07 & $<1.00$ \\
9173 & $<1.00$ & 3.85 & 39.65 & 28.35 & $<1.00$ \\
1.6136 & 1.46 & 3.66 & 15.64 & 4.94 & $<1.00$ \\
M9008 & $<1.00$ & 1.89 & 58.62 & $<1.00$ & $<1.00$ \\
1.5808 & $<1.00$ & $<1.00$ & 4.09 & $<1.00$ & $<1.00$ \\
9188 & $<1.00$ & 1.34 & 48.13 & 3.82 & $<1.00$ \\
8015 & 1.61 & $<1.00$ & 9.98 & 2.94 & $<1.00$ \\
9336 & $<1.00$ & $<1.00$ & $<1.00$ & $<1.00$ & $<1.00$ \\
2.4192 & $<1.00$ & $<1.00$ & $<1.00$ & $<1.00$ & $<1.00$ \\
\hline
\end{tabular}

sites were present inconsistently. Histologically, perivascular lymphocytic infiltrates were present in variable degrees of severity in multiple tissues; lungs, urinary bladder, and abdominal skin were the most consistently involved tissues. Mild lymphocytic hepatitis with or without oval cell hyperplasia was present in all six pigtailed macaques. Cellular apoptosis on intestines was prominent in 4 pigtailed macaques (M9008, I.5808, I.6087, I.6136). Skin lesions at the inoculation sites were varied from minimal perivascular dermatitis to moderate necrotizing epidermitis on pigtailed macaques receiving intra-dermal and subcutaneous viral inoculation.

The dissemination of DEN-3 into distant organs was traced by reverse transcriptase PCR two days after inoculation using primers targeted to amplify the capsid region of DEN-3 in the position of 118-221 of its nucleotide. We detected the virus on variety of tissues in five of six pigtailed macaques (Table 2). In one subcutaneously infected pigtailed macaque (F9004), all tissues were negative by PCR. Of the PCR positive pigtailed macaques, viral RNA was detected in spleen, lung, adrenal gland, kidney, heart, thyroid gland, live and seminal vesicle from pigtailed macaque 1.5799 , in the abdominal skin, spleen, thymus, axillaris lymph node, submandibular lymph node, pancreas, adrenal gland, salivary gland and thyroid gland from pigtailed macaque 1.6087, in abdominal skin, inguinal lymph node and salivary gland from pigtailed macaque 1.6136 , in bone marrow, spleen, salivary gland, liver and mammary gland from pigtailed macaque M9008 and in mesenteric lymph node and liver from pigtailed macaque 1.5808 . 
Table 2 DEN-3 virus were detected in various organ by reverse transcriptase - PCR

\begin{tabular}{|c|c|c|c|c|c|c|}
\hline \multirow{3}{*}{ Tissues } & \multicolumn{6}{|c|}{ Routes of inoculation } \\
\hline & \multicolumn{2}{|c|}{ Subcutaneous } & \multicolumn{2}{|c|}{ Intradermal } & \multicolumn{2}{|c|}{ Intravenous } \\
\hline & $1.5799(\mathrm{M})$ & F9004 (F) & $1.6087(\mathrm{M})$ & $1.6136(\mathrm{~F})$ & M9008 (M) & $1.5808(\mathrm{M})$ \\
\hline Abdominal skin & - & - & + & + & - & - \\
\hline Bone marrow & - & - & - & - & + & - \\
\hline Spleen & + & - & + & - & + & - \\
\hline Thymus & - & - & + & - & - & - \\
\hline Lungs & + & - & - & - & - & - \\
\hline Axilaris lymph gland & - & - & + & - & - & - \\
\hline Inguinalis lymph gland & - & - & - & + & - & - \\
\hline Messenterica lymph gland & - & - & - & - & - & + \\
\hline
\end{tabular}

$\mathrm{M}$, male; F, female.

\section{DISCUSSIONS}

The experiment was designed to examine the dissemination of DEN-3 in a nonhuman primate (NHP) model during acute phase of primary infection. Reports have shown that viremia was detected in NHP after inoculation of DEN viruses through subcutaneous route (Scott et al. 1980; Kochel et al. 2005; Koraka et al. 2007; Bernardo et al. 2008). In this study, three ways of inoculation routes (subcutaneously, intradermally, and intravenously) were performed, in which the subcutaneous and intradermal routes of infection mimic the natural way of transmission of this virus in human. It is somewhat interesting that pigtailed macaques infected intravenously appeared to have the least viral dissemination in tissues, even in pigtailed macaque with high level of viremia. This may be related to the fact that in humans, subcutaneous and intradermal routes of DEN virus infection involved the role of skin dendritic cells (DC) that is believed to be important in the virus replication with DC-SIGN (DCspecific ICAM3-grabbing on integrin ) serving as coreceptor for viral entry (Green and Rothman 2006).

Previous reports have shown that DEN viruses viremia was found starting day 2 post inoculation in Macaca fascicularis (Koraka et al. 2007; Bernardo et al. 2008), M. mulatta (Scott et al. 1980) and M. nemestrina (Wijaya et al. 2010). Increasing viremia levels detected from day 0 to day 2 p.i. in all pigtailed macaques in this study proved that DEN-3 infection and viral replication had occurred in the inoculated pigtailed macaques. To prove that the DEN-3 viral RNA detected in the plasma samples was not a result from unwashed-remaining concentration of virus inoculum, we showed that pigtailed macaques inoculated intradermally and subcutaneously demonstrated high viremia levels, similar to those receiving intravenous viral inoculation.
In this study, we confirmed the presence of the DEN-3 viral RNA in various organs by real time RTPCR. This evidence showed that the DEN-3 had undergone replication in their target cells and organs. The variety of viremia levels in pigtailed macaques within the same group showed that dendritic receptor may play roles in viral replication. Pigtailed macaques with high level of viremia had broader viral dissemination in various organs; the high titer of viruses resulted from replication might be distributed to a wider range of organs. Pigtailed macaques inoculated subcutaneously and intradermally showed wider range of involved organs including spleen, adrenal gland, kidney, thyroid gland, liver, and seminal vesicles, while pigtailed macaques inoculated intravenously had limited viral dissemination in spleen, thymus, salivary gland and prostate gland.

Regardless the viremia level detected in examined tissues, none of the monkeys in this study demonstrated significant pathological changes like that had been described in humans (Basilio-de-Oliviera et al. 2005); hepatitis only present in minimal to mild degree. This supported the fact that none of the pigtailed macaques had any sign of disease during the experiment.

Several human cases of dengue virus infections showed to involve the findings of liver abnormality and viral antigens were detected in patients with hepatic failure secondary to dengue hemorrhagic fever. This study had shown similar condition of hepatitis which was also emphasized with the presence of viral RNA in liver tissue.

To the authors' knowledge, this is the first report of systemic dengue viral dissemination within 2 days after single dose of inoculation in infected $M$. nemestrina. One study has reported the use of $M$. nemestrina as animal model for dengue virus infection (Taweechaisupapong et al. 1996), in where the study 
emphasized on epidermal change due to intradermal inoculation of DEN-2.

Although there was no evidence for hemorrhagic condition in the infected pigtailed macaques as compared to the rhesus macaques (Onlamoon 2010), we still detected the viremia level and viral RNA distribution in tissues after DEN-3 virus infection. We concluded that $M$. nemestrina is a good alternate model to evaluate replication of dengue virus in tissues. Furthermore, by understanding the target cells and organs for DEN-3 replication, such study to reveal the pathogenesis of dengue virus infection that might lead to severe form of disease could be performed.

\section{ACKNOWLEDGEMENTS}

The authors would like to thank I Nengah Budhiarsa and Permanawati for their technical assistance in the husbandry and veterinary care of the animals during the initial stage of the study. This study was partially supported by the State Ministry of Research \& Technology, Republic of Indonesia, through the Incentive Program Research Grant to JP (contract no. 068/RT/D.PSIPTN/insentif/PPK///2009).

\section{REFERENCES}

Basilio-de-Oliveira CA, Aguiar GR, MS Baldanza, Barth OM, Eyer-silva WA, Paes MV. 2005. Phatologic study of a fatal case of dengue-3 virus infection in Rio de Janeiro Brazil. Braz J Infect Dis. 9(4): 341-347. doi:10.1590/S1413.

Bernardo L, Izquierdo A, Prado I, Rosario D, Alvarez M, Santana E, Castro J, Martinez J, Rodriguez R, Morier L, Guillen G, Guzman MG. 2008. Primary and secondary infections of Macaca fascicularis monkey with Asian and American genotypes of dengue virus 2. Clin Vaccine Immunol. 15(3): 439-446. doi: 10.1128/CVI.00208-07.

Bennett BT, Abel CR, Henrickson R. 1998. Nonhuman primates in biomedical research: Diseases. San Diego: Academic Press.

Bente AD, Rico-Hesse R. 2006. Model of dengue virus infection. Drug Discov Today Dis Models. 3(1):97-103. doi: 10.1016/j.ddmod. 2006.03.014
Callahan JD, Wu Shuenn-Jue L, Schultz AD, Mangold BE, Peruski LF, Watts DM, Porter KR, Murphy GR, Suharyono M, King ChwanChuen, Hayes CG, Temenak JJ. 2001. Development and evaluation of serotype and group-spesific fluorogenic reverse transcriptase PCR (Taqman) assay for dengue virus. J Clin Microbiol. 39(11): 4119-4124. doi: 10.1128/JCM.39.11.4119-4124.2001.

De Silva AM, Dittus WPJ, Amerasinghe PH, Amerasinghe FP. 1999. Serologic evidence for an epizootic dengue virus infecting toque macaques (Macaca sinica) at Polonnaruwa, Sri langka. Am J Trop Med Hyg. 60(2): 300-306.

Green S, Rothman A. 2006. Immunophatological mechanisms in dengue and dengue hemorrhagic fever. Curr Opin Infect Dis. 19(5): 429-436.

Kochel TJ, Watts DM, Gonzalo AS, Ewing DF, Porter KR, Russell KL. 2005. Cross-serotype neutralization of dengue virus in Aotus nancyme monkeys. J Infect Dis. 191(6): 1000-1004. doi:10.1086/427511.

Koraka P, Benton S, van Amerongen G, Stittelaar K, Osterhaus ADME. 2007. Characterization of humoral and cellular immune responses in cynomolgus macaques upon primary and subsequent heterologous infections with dengue viruses. Microbes Infect. 9(8):940-946. doi:10.1016/j.micinf.2007.03.012.

Onlamoon N, Noisakran S, Hsiao HM, Duncan A, Villinger F, Ansari AA, Perng GC. 2010. Dengue virus-induced hemorrhage in a nonhuman primate model. Blood. 115(9):1823-1834. doi:10.1182/blood-200909-241990.

Paes MV, Lenzi HL, Nogueira ACM, Nuovo GJ, Pinhao AT, Mota EM, Basilio-de-Oliveira CA, Schatzmayr H, Barth OM, de Barcelos Arves AM. 2009. Hepatic damage associated with dengue-2 virus replication in liver cells of BALB/c mice. Lab Invest. 89:1140-1151. doi:10.1038/labinvest.2009.83.

Peng T, Junlei Zhang, Jing AN. 2004. The animal models for dengue virus infection. Dengue Bul. 428:168-173.

Scott MR, Nisalak A, Eckels KH, Tingpalapong M, Harrison VR, Gould GJ, Chapple FE, Russel PK. 1980. Dengue-2 vaccine: viremia and immune response in rhesus monkeys. Infect Immun. 27(1):181-186.

Taweechaisupapong S, Sriurairatana S, Angsubhakorn S, Yoksan S, Bhamarapravati N. 1996. In vivo and in vitro studies on the morphological change in the monkey epidermal langerhans cells following exposure to dengue 2 (16681) virus. Southeast Asian J Trop Med Public Health. 27(4): 664-672.

Widjaja S, Winoto I, Sturgis J, Maroef CN, Listiyaningsih E, Tan R, Pamungkas J, Iskandriati D, Blair PJ, Sajuthi D, Porter KR. 2010. Macaca nemestrina and dengue virus infectivity: a potential model for evaluating dengue vaccine candidate. Microbiol Indones. 4(2): 49-54.

[WHO] World Health Organization. 2009. Dengue and dengue haemorrhagic fever [internet]. [cited 2009 May 6]. Available from: http://www.who.int/mediacentre/ factsheets/fs117/en/index.html. 